far as it offers explanatory (and not merely descriptive) power, it must posit what cannot be directly observed. Holland's theory of identity is evidence of this fact: despite Holland's caveat that "this identity should be understood . . . as a theme-and-variations representation (not a Ding an sich)," identity, like cause, remains inferred rather than seen. And if identity does not quite have the status of agency in Holland's theory, other terms (for example, feedback) do appear to have this function. This only goes to show that any theory must ultimately posit causes, unseen agencies-precisely at the point, as Lacan notes, where there is a gap in understanding.

Because of this necessity, we find Lacan's model preferable to Schafer's. For while Schafer is quite successful in avoiding the reifications of ego psychology, he pays a price in explanatory power. Lacan, in contrast, retains such concepts as ego ideal, superego, phallus, and castration, thus preserving the discoveries as well as the explanatory power of traditional psychoanalysis. And by reinscribing these concepts as algorithms that cannot be understood apart from all the other algorithms in the psychic equation-many of which involve experienceable linguistic, cognitive, and affective phenomena-Lacan avoids the reifications of ego psychology. Lacanian theory thus offers what we feel is one of the most fertile answers to Holland's question, "What is the relation between the structures of secondphase psychoanalysis and the account of self-processes in third-phase psychoanalysis?"

The fact that this question, as Holland points out, is central to clinical psychoanalysis itself, points to another crucial question not explicitly addressed by our article, which a psychoanalytic theory of reader response must eventually come to grips with: which model of mind gives the most complete and accurate account of the psyche's functioning? Anyone who attempts to gauge the power that literature can have in human affairs must have an (implicit or explicit) answer to this question. Holland's work over the past two decades is evidence that he has seen this point more clearly and pursued it more vigorously and successfully than anyone else in our profession, and we thank him for once again directing our attention to it.

Marshall W. Alcorn, JR. Tulane University

Mark Bracher Kent State University

\section{Shakespeare and Spenser}

To the Editor:

Since A. Kent Hieatt discovered the impact of Spenser's Ruines of Rome on Shakespeare's Sonnets
(PMLA 98 [1983]: 800-14) I have spent some time exploring how other writers anticipated or used the "Ruines complex" of vocabulary, sentiment, and concerns. Thus one of my functions in a collaborative effort with Charles and Kent Hieatt has been to modify the claims my colleagues put forth; like an ungrateful third grace, I reduce the benefits they advance. In this retrogressive role I have found some phrases that we think Shakespeare took from Spenser in poets working before-or during - the probable time of the Sonnets' composition. Two such exceptions have been already noted, one by Gary Schmidgall, who in a letter to PMLA (99 [1984]: 244) pointed out that Barnabe Barnes in 1593 also associated "outwear," "devouring," and "time," and the other by Kent Hieatt himself, who added in his answer to Schmidgall that Spenser had used "time . . . outwear" in The Shepheardes Calender (1579).

Nicholas Grimald's verse also shows a liking for "time" and a form of "wear" (see no. 36 in Tottel's Miscellany [1557], ed. H. E. Rollins). Salisbury's complaint in The Mirror for Magistrates (1559) mistrusts fame, "Which time it selfe must nedes devour" (ed. L. B. Campbell, 143), anticipating Ruines of Rome 3 and 8 and Sonnets 19. True, the Ovidian "tempus edax" would have encouraged this metaphor, but writers often preferred "consume" or "eat," and "devour" is fairly unusual. Then, in the 1587 Mirror, one finds Burdet's complaint referring to "Britaynes first antiquities" (476), another somewhat unusual word that Kent Hieatt considers a link between Spenser and Shakespeare.

I have found only a little of the Ruines of Rome complex in the 1560s or 1570s, but in the mid-1580s it reappears, particularly in the work of Arthur Gorges and Geoffrey Whitney, both of whom knew Du Bellay's poetry and had connections with Spenser or his friends. Gorges, too, conceived of time as wearing. For example, "That to revive which wronge of tyme might weare" (Poems of Sir A. G., ed. H. E. Sandison, 67) translates Du Bellay's "Pour se venger du temps injurieux" in Olive 34. In his Choice of Emblemes (1586) Whitney writes that Elizabeth's fame "no time, nor envie can devower" (106). Time also "wears" in these poems, particularly in the emblem "Scripta Manent" 'Writings Endure,' describing Troy's marble monuments eaten and worn "with tracte of stealinge time" (131). And as in Ruines 7 and Sonnets 15-16, time does battle: it will "winne the feelde" so that our "wonders" are "out of memorie worne" (167). Whitney was keenly interested in how "Rome doth ruine feele" and "Tempus omnia terminat" 'Time ends all things'; before Daniel and Shakespeare he was the poet closest in spirit (if not in talent) to Spenser when writing of such matters.

During the 1590s the Ruines complex may be found fleetingly in the poems published with Constable's $D i$ ana (1592) and in Lodge's verse introduction to Phillis 
(1593), which asserts that no "time out weares" Daniel's fame. Such vocabulary appears more powerfully in Daniel himself and in Drayton. How their poetry is related to Shakespeare's is a complex and disputed topic. My own impression is that the Ruines element in Daniel's Delia (1592) owes a good deal to Du Bellay himself, with an assist from Spenser, and that the significant use of Ruines in Daniel's Rosamund (1592) and Musophilus (1599), together with the less extensive use in the 1595 Civil Wars, constitutes a connected but distinct elaboration of materials Daniel and Shakespeare both found moving. Rosamund says, "Time hath long since worne out" her memory and "Age" has "worne his pleasures out of date" (lines 17-21, 179, in Poems, ed. A. C. Sprague; cf. Shakespeare's "outworn buried age" in sonnet 64). Musophilus mentions "times despight" (line 380), the obverse of "in spite of time" in Ruines, and tells how "time . . . hath laid / Long batterie, back'd with undermining age, / Yet they [the "worthies of antiquitie"] . . . war with his all conquering forces wage" (lines 399-402).

Drayton's intermittent resort to such phrasing may show a debt to Shakespeare, but his evident recollections of Spenser and perhaps of Daniel complicate the situation. Suffice it to note here that in Idea the Shepheards Garland (1593) Drayton says "In spight of death," refers in Piers Gaveston (1594?) to a tomb "Which worlddevouring Time, hath now out-worne," and in Mortimeriados (1596) tells the Countess of Bedford her name will live "in despight of tyranizing times" (Works, ed. J. W. Hebel, 1: 64, 206, 307).

In sum, I have found exceptions to Kent Hieatt's claims of near exclusivity for Spenser's and Shakespeare's fondness for "antiquity," for "in spite of death" or "time," and for combinations of "time" with "war," "outwear," or "devour." Does any of this matter? Not, I think, to his thesis, reinforced by further connections my collaborators have found between Spenser's "compile" and "pencil" (Ruines 25) and Shakespeare's "compile" and "pen" (Sonnets 78 and 85 ); between "was of yore" in Ruines 28 and Sonnets 68 ("yore" used only this once in Sonnets and not found in the other principal sequences, although a precedent appears in The Shepheardes Calender ["September," line 26] and Drayton refers to "antique Romants . . . of yore" in his seventh Idea eclogue [lines 37-38]); and between "worlds sole ornament" in Ruines 29 and "world's fresh ornament" in Sonnets 1. It is the close concentration of Spenser's phrases in Shakespeare's Sonnets that makes Hieatt's thesis convincing. Yet we will continue testing the probable degree of Spenser's impact on Shakespeare by looking for more exceptions, and we should also establish more fully what feelings and imagery about time, burial, Rome, surviving words, and ruined walls were already available to the English when Spenser published Com- plaints and Shakespeare realized that something important had happened to him.

\section{AnNe LAKe Prescott}

Barnard College

Reply:

How to answer a project associate without beating the drums? Prescott's compressed point about "antiquities" is the only one that I consider off center. My claim about "antique" and its forms (unlike my contentions about other such) was quantitative. Spenser used forms of "antique" very frequently in his translation of Du Bellay's Antiquitez-much more than in his other works-but "antique" was a Lieblingswort for him. It was not for Shakespeare, yet he used forms of it in Sonnets very frequently-twenty-five times more frequently than in his other works (and with a similar proportion to each of his other works taken singly).

Otherwise Prescott is just saying what I would like to say, given her information (perhaps with a little more emphasis on Daniel, who, as she implies, probably drew, unlike Shakespeare, on Antiquitez itself). She is further along in finding exceptions than when she wrote the above, but her answer to her own question in her last paragraph remains hers, mine, and the third collaborator's, Charles W. Hieatt's. The three of us are much further along in, and much surprised at, finding verbal agreements between Ruines of Rome and Shakespeare's early histories and (less so) his plays with antique settings. Also, with the help of Aroha Cameron and Kathleen Fraser, we are continuing to establish that these parallels occur nowhere else or are very sparsely scattered in other recognized sources.

We need these verbal bones if we are ever to intuit Shakespeare's transaction with Ruines of Rome. Our chief doubt about our verbal searches lies in the possibility of The Faerie Queene's having bulked larger in Shakespeare's imagination than we have allowed for. Is it likely that Ruines of Rome's concern with time and literary immortality, with the danger of inner strife to an otherwise invincible Rome (read "England" in Shakespeare's histories), and with Rome itself (as in Shakespeare's Roman plays) kept Shakespeare attentive mainly to that work and did not concentrate his mind on Spenser's other works as well? The traditional presumption that Shakespeare attended to The Faerie Queene is supported by comparatively little verbal evidence in the literature (compared, that is, to what we have found in the minor sequence), but then no one ever suggested a verbal connection between Shakespeare's works and the Ruines of Rome until we came along. As Prescott has realized and as Judith Anderson pointed out to me (Hieatt caught by a hiatus in his checking), "was of yore" actually occurs in several 